Scymnus fraternus Lec.?

CUCUIIDE.

Lemophlous convexulus Lec. Rare.

DERMESTIDÆ.

Dermestes bicolor Fabr. One specimen.

Cryptorhopalum ruficorne Lec. Rare.

Orphilus glabratus Er., var, Rare.

HISTERIDA.

Hister defectus Lec.

exaratus Lec.

BYRRHIDA.

Syncalypta echinata Lec. Very abundant a few years ago on the Parliament Buildings, but rarer of late.

DASCYLLIDE.

Scirtes orbiculatus Fabr. Several specimens of this pretty species were taken last summer, on weeds growing along a stream flowing through an old beaver meadow, but owing to the variety of plants growing intermingled, I cannot say on what species it occurred. Previously to last year only one specimen had been taken by me. Cyphon collaris Guer. This species is rare, not more than half a dozen specimens having been captured.

( $T$ o be Continued.)

\title{
CERATOCAMPA (CITHERONIA) REGALIS, FAB.
}

BY JOHN HAMILTON, ALLEGHENY, PA.

In the first number of this volume one of your contributors, Mr. Clarkson, writing about Citheronia regalis, infers that the moth always appears about the end of May, regardless of the time at which the larva. enters the earth, and that it is the habit of the pupa to work out of the earth and lay on the surface of the ground during the winter. The first statement is correct in a certain sense. The insect in question is not uncommon here, and I have had them in numbers. Take a larva captured the first week in August and another the last in September, and allow them 
to pupate in the same box and to remain together-they will disclose within a day or two of each other; but whether at the last of May or at some other time, depends on the temperature at which they have been kept. Keep the pupa of the one taken in August at a temperature a few degrees Jower than that of the September one, and it will disclose much later, perhaps about the time the offspring of the other are entering the earth. I had one pupa that did not disclose till June of the second year. The time of development seems to largely depend on the temperature that surrounds the pupa-a fact that is well known.

The coming of a pupa to the surface is the exception, and not the rule. Those of several other earth-inhabiting species do the same when the ground selected or forced on the larvæ is unsuitable. This occurs in nature as well as in confinement. Take two parts of sandy loam, such as is used by plasterers, and one part of black, friable soil from the woods ; mix together, put, to the depth of eight inches, in a good sized tin or iron box, and when the larvæ disappear cover over with a layer of moss, and then no pupæ will come to the surface.

As soon as the pupa is fully formed it commences a series of gyrations that result in the formation of an earthy cell, roomy, much larger than itself and impervious to ordinary moisture. This prevents it from being crushed by the expansion of the surrounding earth by freezing, and also from shriveling up by the absorption of its moisture in time of drouth; or from drowning from excessive wet. In hard ground the larva cannot penetrate deeply, nor make a wide excavation, and in endeavoring to enlarge its narrow surroundings it wriggles itself to the surface, where it stands small chance to survive to the time of disclosure.

\section{ENTOMOLOGICAL NOTES.}

BY PH. FISCHER, BUFFALO, N. Y.

I have often read articles about keeping parasites out of cabinets, and have seen in many entomological papers different remedies suggested to keep them from destroying, in a very short time, even the largest collection. I will now add my own experience, and remedy which always proved to be efficient during my I 4 years' collecting, in which time $I$ have not even lost one specimen. It will especially prove of interest to the 